International Journal of Instruction e-ISSN: 1308-1470 • www.e-iji.net

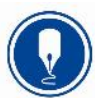

October $2018 \bullet$ Vol.11, No.4

p-ISSN: 1694-609X

pp. $689-700$

Received: 25/05/2018

Revision: $11 / 07 / 2018$

Accepted: 16/07/2018

\title{
Views of Mathematics Student Teachers on Teacher Insights into the Teaching Process
}

\author{
Semiha Kula Ünver \\ Dr., Dokuz Eylül Universty, Turkey, semiha.kula@deu.edu.tr
}

|

The purpose of this study is to determine the views of secondary mathematics student teachers regarding teacher insights -Knowledge Quartet's code- into the teaching process. For this purpose, a case study was conducted. 30 volunteer student teachers were asked whether they notice if their students fail to understand the subject matter of the course and what they would do when they notice. Their answers were analysed using content analysis. The student teachers stated that if their students failed to understand the course subject, they could tell this from their eyes and the way they behave. The other indicators that the teachers mentioned about how they can notice that their students fail to understand the subject, include not answering the questions, lack of interest in lesson, and having misconceptions. The student teachers indicated that when they encountered such situations, they would search for the reason, determine the unclear points, use different methods and techniques, explain the subject again, and so on. To make their students understand more clearly.

Keywords: knowledge quartet, contingency, teacher insight, mathematics student teacher, mathematics education

\section{INTRODUCTION}

The "Knowledge Quartet" (KQ) has been used since 2003 as a framework for the observation, analysis and development of mathematics teaching, with a focus on teachers' subject matter knowledge and pedagogical content knowledge (Rowland, Huckstep, and Thwaites, 2003, 2005; Rowland, 2007; Rowland, Turner, Thwaites, and Huckstep, 2009). The KQ was developed in collaboration with Tim Rowland's colleagues in Cambridge University as part of project named "SKIMA (subject knowledge in mathematics)". They investigated mathematics content knowledge of student teachers, and the ways that this knowledge becomes visible both in their planning and in their teaching in the classroom (Thwaites, Jared, and Rowland, 2011). Thus, rather than considering the generic features of the lesson such as classroom management, etc., the KQ give opportunities to focus on mathematics teaching of the student teachers. In this respect the KQ is a comprehensive tool for thinking about the

Citation: Kula Ünver, S. (2018). Views of Mathematics Student Teachers on Teacher Insights into the Teaching Process. International Journal of Instruction, 11(4), 689-700. https://doi.org/10.12973/iji.2018.11443a 
ways that mathematics subject knowledge comes into play in the classroom environment (Rowland, Huckstep, and Thwaites, 2005). The KQ has four units -called foundation, transformation, connection, and contingency- each of which is associated with several codes that can be seen in Figure 1 (www.knowledgequartet.org).

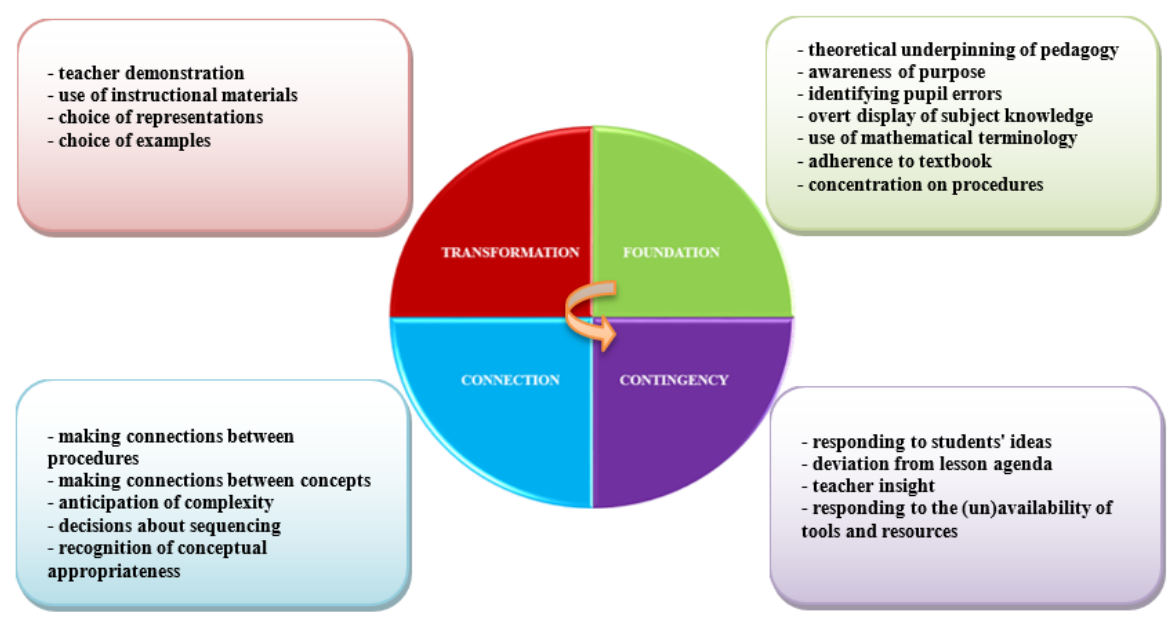

Figure 1

Knowledge Quartet and its codes (Rowland, 2013 cited in Kula \& Bukova Güzel, 2014)

Foundation, the first unit, involves theoretical background on subject matter knowledge and pedagogical content knowledge, as well as beliefs regarding mathematics and mathematics education (Petrou 2009; Thwaites, Huckstep, and Rowland, 2005; Turner 2007). As different from the foundation unit, the remaining three units focus on the ways and contexts in which possessed knowledge is brought to bear on both processes of planning and teaching (Rowland, Huckstep, and Thwaites, 2005; Rowland, et al., 2009; Rowland, 2013). One of these three units, transformation, includes the presentation of the ways in which the teacher's own knowledge is transformed to make it accessible to students (Turner, 2007). Connection includes the selection of mathematical topics, the connections between the decisions taken, the sequencing of topics of instruction within and between lessons, and the ordering of tasks and exercises (Rowland, et al., 2009; Rowland, Thwaites, and Jared 2015). Contingency, the last unit, involves unplanned examples in lessons, students' unexpected ideas, the use of unpredictable opportunities at the time of teaching, and deviation from the lesson agenda in response to an unplanned opportunity (Rowland, Huckstep, and Thwaites, 2003; Turner 2007). MacDonald (1993) states that many undergraduate students studying in teacher education programs feel unprepared about the problems they may face in their professional life (cited in Şahin, Atasoy, and Somyürek, 2010). In this context, it is important to identify contingent actions that student teachers can take in case of unexpected situations, and to evaluate these actions and share the outcomes for further considerations. 
The codes of Contingency are defined as (a) responding to students' ideas, (b) deviation from agenda, (c) responding to the (un)availability of tools and resources, and (d) teacher insight (Rowland, 2013). The code of responding to the student's ideas is concerned with the ability of teachers to give convincing, reasoned, and informative responses to the unexpected ideas and suggestions of students (Rowland, Thwaites, and Jared, 2011). The code of deviation from agenda focuses on how to overcome the situation when encountering a situation that needs to deviate from the designated lesson agenda (Kula, 2011). The code of responding to the (un)availability of tools and resources is concerned with the tools and resources teachers use to materialize, in particular, the abstract concepts (Rowland, Thwaites, and Jared, 2011). Such tools, resources and materials may be the main tool of the lesson agenda, or they may be included in lessons in an opportunistic way (Rowland, Thwaites, and Jared, 2011).

The teacher insight code that forms the focus of this work is important during the teaching process. This is because the ability to detect the disruptions or positive aspects that occur during the lesson shapes the next action. This code also deals with the fact that the teachers notice the deficiencies in the lesson agenda during the course of the actual lesson. Such deficiencies may occur when the example the teacher gave in class is not an ideal example, or when the teacher realizes that the representation that he/she has used is not effective enough to establish the desired connections (Rowland, et al., 2009). For example, in his class, Rowland wrote $n=72$ to show how to find the number of positive integers of a number by using the powers in its prime decomposition, and when he wrote $72=2^{3} \times 3^{2}$, he realized that both 2 and 3 play dual roles in the decomposition, obscuring the significance of the indices as opposed to the specific primes and he thought that this may be confusing for the students (Rowland, Thwaites, and Jared, 2011). Thinking that 72 was not a good example, Rowland wrote 6125 instead of this at once and after making explanations about this number, he told his students why he deleted the number 72 .

In her study, Kula (2014) conceptualized the teacher insights that the student teachers exhibited during lessons when they encountered unexpected situations. As a result of this conceptualization, it has been shown that student teachers' approaches included (a) explaining, (b) reminding, (c) repeating the solution, (d) simplifying the process, (e) changing the content, and (f) submitting it to approval or voting. The mentioned study also highlighted the triggers of these approaches. One of these triggers is the student teachers' ability to realize if their students did not understand the topic. When student teachers noticed such a situation, they used approaches such as explaining, repeating the solution and changing the content.

\begin{abstract}
Aim of the study
When the literature is examined, it is seen that the studies about teacher insight are very limited. However, experienced teachers are more likely to notice deficiencies in their lessons, while inexperienced student teachers have difficulty to overcome these deficiencies (Rowland, Thwaites, and Jared, 2011). Therefore, it is important to conduct studies to identify the insights of the student teachers who are inexperienced or still in their training process. Conducting further studies to improve awareness on teacher
\end{abstract}


insight will contribute to filling the gap in this area. In this respect, the aim of the present study is to explore the opinions of mathematics student teachers regarding their insights into the teaching process.

\section{Research questions}

1. What are the student teachers' views on whether or not they can notice if their students do not understand the subject they are lecturing in the lesson?

2. What are the views of the student teachers regarding the methods they will use if they realize their students did not understand the topic?

\section{METHOD}

In this study, the views of mathematics student teachers regarding teacher insights into the teaching process were examined in detail. In order to do this, the case study methodology, one of the qualitative research methods, was utilized.

\section{Participants}

The participants of this study consist of 30 (nineteen female, eleven male) voluntary secondary mathematics student teachers who took the Teaching Practice course in the second semester of 2015-16 academic year. The participants were in their final year of their education program in a large state university in Turkey. Their grade point average ranges from 2 to 3.57. Student teachers' names were kept confidential and the answer sheets were numbered from 1 to 30 and displayed as $\mathrm{P}_{1}-\mathrm{P}_{30}$ in the results.

The participants have taken the courses such as Calculus, Analytic Geometry, Discrete Mathematics, Differential Equations, Algebra, Complex Analysis, Topology, Probability and Statistics, and so on. They also took courses such as Introduction to Educational Sciences, Curriculum Development, Assessment and Evaluation, Classroom Management, Guidance. For preparing to teach mathematics, they took courses named Mathematical Modeling, Mathematical Problem Solving, Mathematics and Art, Mathematics and Games, History of Mathematics, Mathematical Applications with Computers, Mathematical Thinking, New Approaches in Mathematics, Teaching Methods in Mathematics, and Examination of Mathematics Textbooks. In the last year of their program, there were courses related to school-based placement named School Experience and Teaching Practice.

Participants were enrolled in secondary schools for four hours a week throughout the School Experience course. In this process, they were able to observe mathematics courses at 9-10-11-12th grade. Within the scope of Teaching Practice course, they were found in secondary schools for six hours a week. They have gained teaching experience in this course. The data for this study were collected during the last week of the 14-week Teaching Practice course.

\section{Data Collection Tool}

The data collection tool used in the study consists of the open-ended survey containing student teachers' responses to questions posed to them. The open-ended questions were designed to reveal teachers' views on teacher insights and to answer research questions. 
Then the appropriateness of the open-ended questions was asked to a mathematics teacher educator who has been worked on KQ. It was agreed that the open-ended questions could reveal the views of participants about the teacher insights. The questions are as following:

1. If your students do not understand a subject you are lecturing, can you notice this? How?

2. What do you do when you realize that your students do not understand a subject you are lecturing?

The qualitative methodology requires data to be triangulated. However, in this study, the acquisition of qualitative data from a one data collection tool is one of the limitations of the study.

\section{Data Analysis}

The answers of student teachers to each question were analyzed separately. The responses were read by the researcher repeatedly to gain familiarity with the data. It has been noticed that by reading the data repeatedly, the views of the participants were found to be collected under certain categories. The categories were revealed by the analysis of the data. To form these categories, content analysis was conducted. The main categories generated from the responses were compared with each other at every step and the analysis process continued in this fashion. A mathematics teacher educator was asked to encode 10 randomly selected answer sheets. Then, the reliability of two encoders was calculated using the inter-coder reliability formula which was proposed by Miles and Huberman (1994) and was found to be 0.86. This ratio was considered sufficient for reliability according to Miles and Huberman. The analysis process was concluded by reaching consensus on different categories. The categories emerged from the analysis were presented in Table 1 and Table 2; showing which student teacher belongs to which category and how many teachers were there in each category. While presenting the results, these categories were exemplified by directly quoting from the answer sheets. The participants wrote their views in Turkish then their answers were translated into English.

\section{FINDINGS}

The results of the analysis of the data from the study conducted to determine the views of the mathematics student teachers regarding teacher insights into the teaching process are reflected in Table 1 and Table 2. The answers for each research question were handled separately and the categories are presented in the tables. Student teachers expressed their views as shown in Table 1 on the question about whether or not and how they can notice if their students do not understand a subject they are lecturing in the lesson. 
Table 1

Student teachers' views on whether or not they can notice if their students do not understand the subject they are lecturing in the lesson

\begin{tabular}{lllll}
\hline Condition & How & Student Teacher & $\mathrm{f}$ & $\%$ \\
\hline $\begin{array}{l}\text { Able to } \\
\text { notice }\end{array}$ & Eyes & $\mathrm{P}_{1}-\mathrm{P}_{4}-\mathrm{P}_{5}-\mathrm{P}_{7}-\mathrm{P}_{9}-\mathrm{P}_{11}-\mathrm{P}_{13}-\mathrm{P}_{15}-\mathrm{P}_{18^{-}}$ & 16 & 53 \\
& & $\mathrm{P}_{19}-\mathrm{P}_{20}-\mathrm{P}_{23}-\mathrm{P}_{24}-\mathrm{P}_{26}-\mathrm{P}_{29}-\mathrm{P}_{30}$ & & \\
& Not answering the questions & $\mathrm{P}_{4}-\mathrm{P}_{5}-\mathrm{P}_{7}-\mathrm{P}_{8}-\mathrm{P}_{9}-\mathrm{P}_{10}-\mathrm{P}_{16}-\mathrm{P}_{17}-\mathrm{P} 18-$ & 14 & 46 \\
& $\mathrm{P}_{21}-\mathrm{P}_{22}-\mathrm{P}_{25}-\mathrm{P}_{27}-\mathrm{P}_{30}$ & & \\
& $\mathrm{P}_{1}-\mathrm{P}_{5}-\mathrm{P}_{6}-\mathrm{P}_{7}-\mathrm{P}_{15}-\mathrm{P}_{17}-\mathrm{P}_{18}-\mathrm{P}_{19}-\mathrm{P}_{24}-$ & 10 & 33 \\
& Attitudes & $\mathrm{P}_{28}$ & 7 & 23 \\
& Not interested in the lesson & $\mathrm{P}_{4}-\mathrm{P}_{8}-\mathrm{P}_{16}-\mathrm{P}_{20}-\mathrm{P}_{23}-\mathrm{P}_{25}-\mathrm{P}_{30}$ & 5 & 16 \\
& $\begin{array}{l}\text { Asking questions } \\
\text { Having misconceptions }\end{array}$ & $\mathrm{P}_{1}-\mathrm{P}_{2}-\mathrm{P}_{12}-\mathrm{P}_{23}-\mathrm{P}_{29}$ & 1 & 3 \\
& $\mathrm{P}_{14}$ & 1 & 3 \\
$\begin{array}{l}\text { Naining experience } \\
\text { Not able notice }\end{array}$ & $\mathrm{P}_{28}$ & 1 & 3 \\
\hline
\end{tabular}

The views of the student teachers are reflected in Table 1 as being able to notice or not able to notice when their students do not understand the subject lectured during the lesson. Twenty-nine of the student teachers stated that they would notice if their students did not understand. Only one of the student teachers stated that he/she may not be able to realize if his/her students did not understand the subject. Here are the statements of the student teacher $\left(\mathrm{P}_{3}\right)$ from the answer sheet, indicating that he/she will expect for them to say they do not understand.

I do not think I can notice. So, I expect them to say that they did not understand. $\left(\mathrm{P}_{3}\right.$ 's view)

Student teachers stated that, by their own efforts or by observing their students' actions, they can determine whether or not their students understood the subject lectured in class. More than half of the student teachers stated that if their students did not understand the subject, they could tell this from students' eyes. The opinion of $\mathrm{P}_{1}$ in this regard is as follows.

I can feel whether or not my students understood the subject that I am lecturing. It is quite easy to tell this from students' eyes and attitudes. ( $\mathrm{P}_{1}$ 's view)

Fourteen of the student teachers stated that they would realize that their students did not understand the subject, when students are not answering the questions they were posed. Participant number 4 stated that he/she may realize that his/her students did not understand the course subject when they participate less in class or when they cannot answer the questions they were asked. The thoughts of $\mathrm{P}_{4}$ regarding this point of view are as follows.

I can notice that my students did not understand a certain topic from their participation in class, from their inability to answer the questions I ask to them, and even sometimes from how they look at me and the notes on the board. $\left(\mathrm{P}_{4}\right.$ 's view) 
Student teachers stated that they would take into account the observable behaviors of students such as their features, actions and gestures. According to this view, when students did not understand the subject, this would be reflected in their eyes and gestures. $\mathrm{P}_{15}$ among ten student teachers, who say that they could notice that their student did not understand the course subject from students' attitudes, stated this as follows.

It is understood from the students' eyes and attitudes that they did not understand the subject. $\left(\mathrm{P}_{15}\right.$ 's view)

Student teachers stated that when students cannot understand the lesson, they may divert their attention to another direction instead of paying attention to the lesson. Seven student teachers stated that they can notice that their students having trouble understanding the lesson by looking at whether or not the students are focused on the lesson. In the $\mathrm{P}_{25}$ 's answer sheet, this is stated as follows.

I think I can. If students do not understand the subject, they will lose interest in the lesson, they cannot answer the questions correctly, and if the situation continues they start to deal with different things other than the lesson. $\left(\mathrm{P}_{25}\right.$ 's view $)$

A student teacher $\left(\mathrm{P}_{14}\right)$, on the other hand, stated that one can also recognize that the students did not understand the subject, if they have misconceptions about it.

If I see they have misconceptions about the subject after I lecture them, I realize that they did not understand. ( $\mathrm{P}_{14}$ 's view)

Five of the student teachers stated that they would realize that their students did not understand the subject by asking them questions. However, a student teacher $\left(\mathrm{P}_{28}\right)$ stated that as student teachers gain experience, they will be more able to realize if their students do not understand the lesson.

As I gain experience in the teaching profession, I believe I will be able to realize if my students do not understand the subject. $\left(\mathrm{P}_{28}\right.$ 's view)

The analysis of data related to the second research question were presented in the Table 2. The opinions of the student teachers regarding the methods they will use if they realize their students did not understand the topic are given in the following table. 
Table 2

The views of the student teachers regarding the methods they will use if they realize their students did not understand the topic

\begin{tabular}{llll}
\hline Method & Student teacher & $\mathrm{f}$ & $\%$ \\
\hline Using different method- & $\mathrm{P}_{1}-\mathrm{P}_{4}-\mathrm{P}_{8}-\mathrm{P}_{10}-\mathrm{P}_{12}-\mathrm{P}_{14}-\mathrm{P}_{17}-\mathrm{P}_{18}-\mathrm{P}_{20}-\mathrm{P}_{23}-\mathrm{P}_{24^{-}}$ & 16 & 53 \\
technique & $\mathrm{P}_{26}-\mathrm{P}_{27}-\mathrm{P}_{28}-\mathrm{P}_{29}-\mathrm{P}_{30}$ & & \\
Teaching the subject again & $\mathrm{P}_{4}-\mathrm{P}_{6}-\mathrm{P}_{7}-\mathrm{P}_{9}-\mathrm{P}_{12}-\mathrm{P}_{19}-\mathrm{P}_{21}-\mathrm{P}_{23}-\mathrm{P}_{25}-\mathrm{P}_{30}$ & 10 & 33 \\
Specifying the unclear points & $\mathrm{P}_{1}-\mathrm{P}_{2}-\mathrm{P}_{9}-\mathrm{P}_{15}-\mathrm{P}_{20}-\mathrm{P}_{22}-\mathrm{P}_{24}-\mathrm{P}_{30}$ & 8 & 26 \\
Teaching in different ways & $\mathrm{P}_{5}-\mathrm{P}_{7}-\mathrm{P}_{11}-\mathrm{P}_{13}-\mathrm{P}_{16}-\mathrm{P}_{22}-\mathrm{P}_{25}$ & 7 & 23 \\
Solving different examples & $\mathrm{P}_{12}-\mathrm{P}_{18}-\mathrm{P}_{19}-\mathrm{P}_{21}-\mathrm{P}_{27}$ & 5 & 16 \\
Using materials & $\mathrm{P}_{6}-\mathrm{P}_{8}-\mathrm{P}_{21}-\mathrm{P}_{22}$ & 4 & 13 \\
Preparing different activities & $\mathrm{P}_{4}-\mathrm{P}_{11}-\mathrm{P}_{15}-\mathrm{P}_{17}$ & 4 & 13 \\
Attracting attention & $\mathrm{P}_{7}-\mathrm{P}_{8}-\mathrm{P}_{30}$ & 3 & 10 \\
Using math software & $\mathrm{P}_{8}-\mathrm{P}_{22}$ & 2 & 7 \\
Examining the reasons of not & $\mathrm{P}_{1}-\mathrm{P}_{20}$ & 2 & 7 \\
understanding & & & \\
Checking own knowledge & $\mathrm{P}_{17}$ & 1 & 3 \\
Peer Teaching & $\mathrm{P}_{18}$ & 1 & 3 \\
Getting feedback & $\mathrm{P}_{24}$ & 1 & 3 \\
Correcting mistakes & $\mathrm{P}_{27}$ & 1 & 3 \\
Giving examples from daily life & $\mathrm{P}_{28}$ & 1 \\
\hline
\end{tabular}

When students did not understand a subject, the half of the student teachers stated that they would use different methods and techniques. They expressed their opinion that this change would be useful on the ground that the methods and techniques that were used in the lecture were the reasons that lead students to not understanding the subject. . The related view of $\mathrm{P}_{23}$ is given below.

Another way is to change the lecturing technique. A more appropriate method for the student profile can be used. $\left(\mathrm{P}_{23}\right.$ 's view)

$\mathrm{P}_{12}$ is one of the student teachers who stated that they would teach the subject again; the statements on his/her answer sheet are as follows.

If they did not understand, I would teach the lesson again. Covering the subject once again, would ensure that the missing parts and the points they did not understand are made up. $\left(\mathrm{P}_{12}\right.$ 's view)

Eight of the student teachers stated that, firstly, they would specify the points that are not understood. They also expressed their opinions on what to do after this. These opinions are also given in Table 2. The statements on the answer sheet of $\mathrm{P}_{20}$ are as follows.

First, I communicate with students and detect what they did not understand. $\left(\mathrm{P}_{20}\right.$ 's view)

Seven student teachers stated that they would lecture on the subject in different ways and five student teachers stated that they would solve different examples, upon realizing that the students did not understand the subject. $\mathrm{P}_{19}$ stated that he/she would solve new 
examples on the board with the students who did not understand the subject. The statements of $\mathrm{P}_{19}$ are as follows:

I especially choose the students whom I could tell from their eyes that did not understand the lesson, and I would solve new examples on the board with them. They would understand different points they did not understand before. $\left(\mathrm{P}_{19}\right.$ 's view)

Four student teachers stated that they would help their students to understand course subject by using materials and four of them said they would prepare different activities. $\mathrm{P}_{8}$ stated that he/she can use materials to draw students' attention to the lesson and can benefit from the mathematical software, and said that he/she would help the students to understand the subject by performing applications in GeoGebra. $\mathrm{P}_{17}$ stated that the he/she would cover the subject again through a different activity.

The first thing I do when I notice this [that the students did not understand] is to attract attention. I can change the teaching method and technique for this. I can use material and mathematical software. For example, I can immediately open the computer and apply GeoGebra for the specific point they do not understand. ( $\mathrm{P}_{8}$ 's view)

I would lecture again, using a different activity. Thus, we would be able to cover the subject they did not understand through another activity. $\left(\mathrm{P}_{17}\right.$ 's view)

Two of the student teachers stated that they would do something to attract students' attention; two of them said that they would use mathematics software; and two of them reflected that they would examine the reasons of not understanding when they felt that their students did not understand the course subject. However, one student teacher stated that he/she would check his/her own knowledge, one said that he/she would apply peer teaching, one told that he/she would try to get feedback, one stated that he/she would correct the students' mistakes and one said that he/she would give students an example from everyday life.

\section{DISCUSSION, CONCLUSIONS AND SUGGESTIONS}

Through this study which was conducted to determine the opinions of mathematics student teachers regarding the insights into the teaching process, and in line with the answers of student teachers, also the information, on which path that the student teachers would follow, was obtained. In this context, it has been revealed from this study that the teacher insights are predominantly shaped by the actions, discourses, features, attitudes and gestures of the students. Student teachers have stated that if their students did not understand the subject matter of the course, they would tell this from their eyes and attitudes. In addition, students who are not answering the questions or not interested in the lesson, and students who have misconceptions are regarded by student teachers as other indicators to realize that their students did not understand the subject. Student teachers also stated that in order to realize that whether or not the students understand a course subject, they can ask questions. Likewise, a student teacher in Baştürk and 
Dönmez's (2011) study stated that he/she can determine his/her students' understanding of the subject by asking them various questions about the subject.

A student teacher has pointed out the importance of experience when realizing whether or not the students understand the subject. Similarly, Rowland, Thwaites and Jared (2011) noted that deficiencies were more easily recognized by experienced teachers. From this point of view, it is important for student teachers who are still in the training process to gain experience, especially in the real class environment.

In addition to what the student teachers have stated, the students' understanding of the topic can be determined in different ways. For example, Baştürk and Dönmez (2011) stated that a student teacher's students ask questions about different representations about the topic and another student teacher ask them to give examples from daily life to determine whether or not the students understood the subject. Teachers in the study of Kılıç (2014) stated that they can realize whether or not their students understand the subject by asking their students to pose problems. Another way to realize students' understanding is to observe them and to determine whether or not they follow the teacher (Baysen, Soylu, and Baysen, 2003).

Student teachers stated that, they would try to find out why their students failed to understand, specify unclear points in the lesson, use different methods and techniques, solve different examples, prepare different activities, use mathematical software and material, when they realize their students did not understand the course subject. Student teachers who participated in Kula's (2014) study have also tried to change their lesson content to help their students understand. By using activities and worksheets containing different learning styles, teachers will contribute to learners' not only proper understanding of the concepts but reinforcing them (Bukova Güzel, Elçi, and Alkan, 2006; Elçi, Bukova Güzel, and Alkan, 2006a, 2006b).

Rowland, Thwaites and Jared (2015) state that the teacher insight was less common in novice-teacher data although seasoned teachers might recognize it in their own experience. For this reason, environments should be prepared to ensure that student teachers gain teacher insight during their education (Bukova Güzel, 2010). In this study, the teacher insights of student teachers were tried to be identified by analyzing their answers to open-ended questions. This identification is important in terms of obtaining student teachers' views, but limited because they are away from the classroom environment. For this reason, scenarios based on classroom conversations can be studied and discussed with student teachers. Besides, it is thought that determining how student teachers reflect teacher insights into the real classroom environment would contribute to the field. Thus, the ways in which teachers can instantly take contingent actions to overcome unexpected situations would also be explored. How can student teachers develop teacher insight is also a question that needs to be studied.

\section{REFERENCES}

Baştürk, S., \& Dönmez, G. (2011). Investigating mathematics student teachers' pedagogical content knowledge in the context of knowledge of assessmen. Ahi Evran University Kırşehir Education Faculty Journal, 12/3, 17-37. 
Baysen, E., Soylu, H., \& Baysen, F. (2003). Questioning and listening durations. Gazi University Kastamonu Education Journal, 11/1, 53-58.

Bukova Güzel, E. (2010). An investigation of pre-service mathematics teachers' pedagogical content knowledge: Example of solid objects. Scientific Research and Essays, 5/14, 1872-1880.

Bukova Güzel, E., Elçi, A. N., \& Alkan, H. (2006). Activities for Learning Function Concept in Constructivist Learning Environment. Contemporary Trends in EducationIII: Symposium on Constructivism and Educational Reflections, İzmir.

Elçi, A. N., Bukova Güzel, E., \& Alkan, H. (2006a). Creating Mathematical Concepts with Multidimensional Activity Approaches. VII. National Science and Mathematics Education Congress, Ankara.

Elçi, A. N., Bukova Güzel, E., \& Alkan, H. (2006b). Worksheet Suitable for the Constructivist Learning Approach. Contemporary Trends in Education-III: Symposium on Constructivism and Educational Reflections, İzmir.

Kılıç, Ç. (2014). Determination of primary teachers' perception forms related to problem posing. Kastamonu Education Journal, 22/1, 203-214.

Kula, S. (2011). Examining Mathematics Pre-service Teachers' Subject Matter and Pedagogical Content Knowledge by Using Knowledge Quartet: The Case of Limit. Master Thesis, Dokuz Eylül University, İzmir, Türkiye.

Kula, S. (2014). Conceptualizing Mathematics Pre-Service Teachers' Approaches towards Contingency in Teaching Process in the Context of Knowledge Quartet. Doctoral Dissertation, Dokuz Eylül University, İzmir, Türkiye.

Kula, S. ve Bukova Güzel, E. (2014). Knowledge Quartet's unit of Contingency in the light of mathematics and mathematics content knowledge. Turkish Journal of Computer and Mathematics Education, 5(1), 89-107.7

Miles, M. B., \& Huberman, A. M. (1994). Qualitative Data Analysis: A Sourcebook of New Methods (second edition). Beverly Hills: Sage Publications

Petrou, M. (2009). Adapting the knowledge quartet in the Cypriot mathematics classroom. In Proceedings of the 6th Congress of the European Society for Research in Mathematics Education (pp. 2020-2029).

Rowland, T. (2007). Developing knowledge for teaching: A theoretical loop. In: S. Close, D. Corcoran, \& T. Dooley (Eds.), Proceedings of the 2nd National Conference on Research in Mathematics Education (pp. 14-27). Dublin: St Patrick's College.

Rowland, T. (2013). The Knowledge Quartet: the genesis and application of a framework for analysing mathematics teaching and deepening teachers' mathematics knowledge. Sisyphus-Journal of Education, 1/3, 15-43. 
Rowland, T., Huckstep, P., \& Thwaites, A. (2003). The Knowledge Quartet. Proceedings of the British Society for Research into Learning Mathematics. 23(3), 97102.

Rowland, T., Huckstep, P., \& Thwaites, A. (2005). Elementary teachers' mathematics subject knowledge: The Knowledge Quartet and the case of Naomi. Journal of Mathematics Teacher Education, 8/3, 255-281.

Rowland, T., Thwaites, A., \& Jared, L. (2011). Triggers of Contingency in Mathematics Teaching. In B. Ubuz (Ed.). Proceedings of the 35th Conference of the International Group for the Psychology of Mathematics Education, 4, 73-80. Ankara, Turkey.

Rowland, T., Thwaites, A., \& Jared, L. (2015). Triggers of contingency in mathematics teaching. Research in Mathematics Education, 17/2, 74-91.

Rowland, T., Turner, F., Thwaites, A., \& Huckstep, P. (2009). Developing Primary Mathematics Teaching: Reflecting on Practice with the Knowledge Quartet. London: Sage.

Şahin, S., Atasoy, B., \& Somyürek, S. (2010). Cases method in teacher education. Gaziantep University Journal of Social Sciences, 9/2, 253-277.

Thwaites, A., Huckstep, P., \& Rowland, T. (2005). The Knowledge Quartet: Sonia's Reflections. In D. Hewitt and A. Noyes (Eds) Proceedings of the Sixth British Congress of Mathematics Education (168-175). London: British Society for Research into Learning Mathematics.

Thwaites, A., Jared, L., \& Rowland, T. (2011). Analysing secondary mathematics teaching with the Knowledge Quartet. Research in Mathematics Education, 13(2), 227228.

Turner, F. (2007). Development in the Mathematics Teaching of Beginning Elementary School Teachers: An Approach Based on Focused Reflections. Proceedings of the Second National Conference on Research in Mathematics Education, Mathematics in Ireland. 2, (pp. 377-386). Dublin: St Patrick's College. 